\title{
RESPON PRODUKSI AYAM PETELUR TERHADAP PEMBERIAN PROBIOTIK TEPUNG DAN TEPUNG BELIMBING WULUH DALAM PAKAN
}

\author{
Desna Ayu Wijayanti ${ }^{1)}$ dan Dimas Fajar Nugroho') \\ 1) Akademi Peternakan Karanganyar, Jl. Lawu No. 115 Karanganyar, Telp (0271) 495212, \\ email:desnawijayanti@gmail.com \\ 2) Akademi Peternakan Karanganyar, Jl. Lawu No. 115 Karanganyar, Telp (0271) 495212, \\ email:fajarresmi@gmail.com
}

\begin{abstract}
Abstrak
Penelitian dilakukan untuk mengetahui respon produksi ayam petelur terhadap pemberian kombinasi probiotik bentuk tepung dan tepung belimbing wuluh sebagai pengganti antibiotik komersial dalam pakan. Sebanyak 240 ekor ayam petelur strain Lohmann Brown, umur 22 minggu dikelompkkan menjadi 5 perlakuan dan 6 ulangan, yang terdiri dari P0: $0 \%, \mathrm{P} 1: 0,8 \%$ probiotik bentuk tepung $+0,25 \%$ tepung belimbing wuluh, $\mathrm{P} 2: 0,8 \%$ probiotik bentuk tepung $+0,50 \%$ tepung belimbing wuluh, P3: 0,8\% probiotik bentuk tepung $+0,75 \%$ tepung belimbing wuluh. Variabel yang diukur adalah konsumsi pakan, Hen Day Production (HDP), berat telur, egg mass dan konversi pakan. Data yang diperoleh dianalisis dengan analisis sidik ragam (ANOVA) pola Rancangan Acak Lengkap (RAL) dan apabila terdapat perbedaan, dilanjutkan dengan Uji Jarak Berganda Duncan. Hasil penelitian menunjukkan bahwa perlakuan tidak memberikan pengaruh nyata $(P>0,05)$ terhadap penampilan produksi ayam petelur yang terdiri dari konsumsi pakan, HDP, berat telur, egg mass dan konversi pakan. Kesimpulan dari penelitian ini adalah penambahan kombinasi probiotik bentuk tepung dan tepung belimbing wuluh dalam pakan, belum dapat meningkatkan penampilan produksi ayam petelur, tetapi pada perlakuan P3 menunjukkan kecenderungan hasil yang baik diantara semua perlakuan.
\end{abstract}

Kata kunci: ayam petelur, belimbing wuluh, penampilan produksi, probiotik

\section{Abstract}

The purpose of this research to determine the response of a combination of probiotic powder and bilimbi powder as a substitute for commercial antibiotics on the performance of laying hens. The materials used were 240 laying hens (Lohmann Brown strain), 22 weeks. The research designed by 4 treatments and 6 replications. The treatments applied on feed and consisted of T0: $0 \%, T 1: 0.8$ probiotic powder $+0.25 \%$ bilimbi powder, T2: 0.8 probiotic powder $+0.50 \%$ bilimbi powder and T3: 0.8 probiotic powder $+0.75 \%$ bilimbi powder. The observed variables were the feed intake, hen day production (HDP), egg weight, egg mass and feed conversion ratio (FCR). The data were analayzed of ANOVA using Completely Randomized Design (CRD), and if there were differences, followed by Duncan's Multuple Rang Test (DMRT). The result showed that the treatments gave no significantly effect (T>0.05) on the feed intake, HDP, egg weight, egg mass and FCR. The conclusion of this study was the addition of a combination of probiotic powder and bilimbi powder, has not been able to improve performance of laying hens, but the treatment of T3 showed a trend towards best result among all treatments.

Keywords: bilimbi powder, laying hen, probiotic, production performance

\section{PENDAHULUAN}

Perkembangan ilmu pengetahuan dan teknologi, khususnya dibidang peternakan dan kesehatan hewan ditunjukkan dengan adanya teknologi baru yang mengarah untuk mencapai efisiensi penggunaan input produksi pada usaha ternak.

Perkembangan teknologi tersebut, diterapkan sebagai alternatif pengganti dari antibiotik komersil atau yang sering dikenal dengan Antibiotic Growth Promotor (AGP), seperti teknologi penggunaan mikroba. Hal tersebut 
sejalan dengan diberlakukannya peraturan menteri pertanian (Permentan No. 14 Pasal 16 Tahun 2017) tentang klasifikasi obat hewan yang menghendaki untuk memberhentikan segala penggunaan antibiotik yang digunakan sebagai imbuhan pakan (feed additive).

Wujud dari teknologi penggunaan mikroba dalam hal ini diantaranya probiotik dan asam organik yang berasal dari bahan alami. Penggunaan bahan-bahan tersebut diharapkan mampu meningkatkan efisiensi pakan dan tidak memberikan efek ataupun dampak yang buruk terhadap kondisi saluran cerna dan produktivitas ternak seperti halnya pada antibiotik komersil yang dapat menimbulkan mikroorganisme resisten dalam tubuh ternak, terutama pada mikroba patogen seperti Escherichia coli dan Salmonella sp.

Kabar baiknya, penggunaan probiotik dilaporkan mampu menjaga kesehatan saluran cerna (Reid, 2016), yaitu dengan memanfaatkan peran dari mikroba probiotik untuk menyeimbangkan populasi mikroba, sehingga saluran pencernaan mampu memaksimalkan penyerapan nutrisi dan berpengaruh terhadap produktivitas ternak (Sharma et.al, 2016).

Pemberian probiotik sebagai aditif pakan, dalam aplikasinya dapat diberikan dalam bentuk tunggal ataupun dengan campuran zat penghambat lain yang memiliki efek sinergis, yaitu yang menguntungkan bagi ternak (Haryanto, 2000). Salah satu zat penghambat lain yang penggunaannya dapat dikombinasikan dengan probiotik untuk mengoptimalkan kondisi saluran pencernaan melalui peran pertumbuhan mikroba patogen yaitu asam organik atau yang sering dikenal dengan acidifier.

Sistem kerja dari asam organik yaitu dengan meningkatan keasaman pada saluran pencernaan, dari keasaman tersebut maka asam organik mampu menghambat pertumbuhan mikroba patogen. Sumber asam organik yang digunakan dalam penelitian ini merupakan asam dari belimbing wuluh. Asam yang terkandung dalam belimbing wuluh terdiri dari asam laktat, asam sitrat, asam asetat, asam format, asam oksalat (Yuliansyah, Widodo dan Djunaidi, 2014) dan juga mengandung asam askorbat/ vitamin C (Hutajulu, Azizah, dan Suherman, 2009). Kombinasi antara probiotik dengan asam organik mempunyai peran yang sinergis, keduanya mampu menghasilkan asamasam organik yang dapat menghambat pertumbuhan mikroba, termasuk mikrobamikroba patogen yang ada pada saluran cerna ternak seperti Escherichia coli dan Salmonella enteritidis (Jannah et.al, 2014).

Uraian diatas menjadi hal yang menarik untuk dilakukan penelitian dalam melihat respon produksi terhadap penggunaan kombinasi probiotik dan asam organik dalam bentuk tepung pada ayam petelur, dilihat dari aspek konsumsi pakan, HDP, berat telur, egg mass dan konversi pakan.

\section{BAHAN DAN METODE}

\section{Bahan}

Bahan yang digunakan dalam penelitian ini terdiri dari ayam petelur (strain Lohmann Brown, umur 22 minggu, 240 ekor), probiotik (Lactobacillus sp. dan Bacillus sp. dalam bentuk tepung), tepung belimbing wuluh dan pakan semi self mix. Penelitian dilakukan selama 6 minggu, di peternakan ayam petelur milik pribadi di Kabupaten Karanganyar.

\section{Metode}

Metode yang digunakan dalam penelitian ini adalah metode percobaan dengan menggunakan Rancangan Acak Lengkap (RAL). Percobaan terdiri dari 4 perlakuan dan 6 ulangan, setiap ulangan terdiri dari 10 ekor. Perlakuan terdiri dari:

P0(-) : pakan basal tanpa penambahan aditif pakan

P1 : probiotik tepung $0,8 \%+$ tepung belimbing wuluh $0,25 \%$

P2 : probiotik tepung $0,8 \%+$ tepung belimbing wuluh $0,50 \%$

P3 : probiotik tepung $0,8 \%$ + tepung belimbing wuluh $0,75 \%$ 
Penambahan imbuhan pakan probiotik dan asam organik dari tepung belimbing wuluh tersebut tidak akan mempengaruhi formulasi pakan, sehingga kandungan nutrisi pada pakan pada tiap perlakuan sama. Probiotik dan asam organik ditambahkan dalam bentuk tepung bertujuan untuk mempermudah ketika homogenisasi dalam pakan.

Prosedur pembuatan tepung belimbing wuluh yang digunakan dalam penelitian ini yaitu, dimulai dari pengelompokkan buah belimbing wuluh berdasarkan pada keseragaman fisiknya (buah matang), setelah menjadi kering, diparut dan kemudian dikeringkan (biasanya terdapat perubahan warna menjadi kecoklatan) dan tahap terakhir yaitu di grinding untuk memperkecil ukuran dan berbentuk menjadi tepung.

\section{Variabel Penelitian}

Variabel yang diamati pada penelitian pemberian probiotik tepung dan tepung belimbing wuluh, sebagai berikut:

a. Konsumsi pakan (g/ekor) = pakan yang diberikan (g) - pakan yang tersisa $(\mathrm{g})$

b. Hen Day Production (HDP) $(\%)=(\Sigma$ produksi telur hari ini (butir) $/ \Sigma$ ayam yang ada) x $100 \%$

c. Berat telur (g)

d. Egg mass $(\mathrm{g})=\mathrm{HDP}(\%) \times$ berat telur $(\mathrm{g})$

e. Konversi Pakan = konsumsi pakan $(\mathrm{g}) / \mathrm{egg}$ mass $(\mathrm{g})$

\section{Analisis Data}

Data yang telah diperoleh ditabulasi menggunakan Microsoft Excel dan dianalisis secara statistik sesuai dengan perhitungan pada metode yang digunakan. Apabila terdapat perbedaan pengaruh diantara perlakuan, maka dilanjutkan dengan Uji Jarak Berganda Duncan's (UJBD).

\section{HASIL DAN PEMBAHASAN}

Data hasil penelitian dari respon produksi ayam petelur terhadap pemberian perlakuan probiotik bentuk tepung dan tepung belimbing wuluh ditampilkan secara lengkap pada Tabel 1.

\section{Konsumsi Pakan}

Hasil penelitian menunjukkan bahwa dengan pemberian probiotik tepung dan tepung belimbing wuluh dalam pakan tidak memberikan perbedaan yang nyata $(P>0,05)$ terhadap konsumsi pakan ayam petelur. Manin, Hendalia, Yusrizal dan Nurhayati (2005) dalam penelitiannya juga menyatakan bahwa perlakuan probiotik belum memberikan pengaruh yang signifikan terhadap konsumsi pakan. Hasil penelitian tersebut dapat diasumsikan bahwa imbuhan pakan yang ditambahkan dalam penelitian bersifat nonnutritive, sehingga penambahan level yang berbeda pada tiap perlakuan tidak merubah kandungan nutrisi dari pakan basal. Sejalan dengan Hendalia, Manin, Yusrizal dan Nasution (2012), probotik bukan merupakan bagian dari sumber nutrien, sehingga dengan adanya probiotik dalam pakan tidak akan memberikan pengaruh yang besar terhadap peningkatan intake nutrient, terkhusus pada protein kasar.

Tabel 1. Rataan Respon Produksi Ayam Petelur Terhadap Pemberian Probiotik Tepung Dan Tepung Belimbing Wuluh Dalam Pakan

\begin{tabular}{lcccc}
\hline \multicolumn{1}{c}{ Perlakuan } & P0 & P1 & P2 & P3 \\
\hline Konsumsi Pakan & $109,39 \pm 1,52$ & $109,34 \pm 1,21$ & $108,45 \pm 1,39$ & $107,90 \pm 1,76$ \\
(g/ekor/hari) & $73,70 \pm 1,90$ & $74,18 \pm 1,03$ & $73,95 \pm 1,73$ & $74,73 \pm 1,72$ \\
HDP (\%) & $54,41 \pm 1,13$ & $54,49 \pm 0,74$ & $54,46 \pm 1,22$ & $55,05 \pm 1,50$ \\
Berat telur (g/butir) & $40,10 \pm 1,23$ & $40,42 \pm 0,53$ & $40,28 \pm 1,72$ & $41,14 \pm 1,58$ \\
Egg mass & $2,73 \pm 0,10$ & $2,71 \pm 0,06$ & $2,70 \pm 0,11$ & $2,63 \pm 0,09$ \\
(g/ekor/hari) & & & & \\
\hline
\end{tabular}


Meskipun tidak menunjukkan pengaruh yang signifikan, dapat diketahui pada Tabel 1, terdapat kecenderungan penurunan rataan konsumsi pakan pada perlakuan P3 dengan rataan konsumsi pakan $(107,90 \pm 1,76)$ g/ekor/hari. Hasil tersebut menunjukkan adanya reaksi kerja dari probiotik dan belimbing wuluh yang mampu mengefisienkan konsumsi pakan. Menurut Astuti, Busono dan Sjofjan (2015), bakteri probiotik didalam saluran pencernaan melakukan kompetisi terhadap bakteri patogen hingga akhirnya jumlah bakteri non patogen mendominasi dan mampu mengoptimalkan pencernaan makanan di saluran cerna sehingga mampu mengefisienkan konsumsi pakan dan konsumsi pakan cenderung menurun. Menurut Kompiang (2000), probiotik dengan beberapa kombinasi lainnya dalam pakan mampu menggantikan fungsi dari antibiotik yang selama ini sebagai salah satu growth promotor.

\section{Hen Day Production (HDP)}

Selaras dengan konsumsi pakan, hasil penelitian (Tabel 1.) penambahan probiotik tepung dan tepung belimbing wuluh dalam pakan tidak memberikan perbedaan yang nyata $(P>0,05)$ terhadap produksi telur atau HDP. Secara statistik menunjukkan tidak adanya pengaruh antar perlakuan, namun bila dilihat rataan di setiap perlakuan terdapat kecenderungan peningkatan di setiap kenaikan level penggunaan perlakuan dari imbuhan pakan. Artinya, penambahan probiotik tepung dan tepung belimbing wuluh ini mampu meningkatkan produksi telur atau HDP meskipun tidak secara signifikan.

Perlakuan P3 merupakan perlakuaan yang menunjukkan rataan produksi telur yang paling tinggi sebesar $(74,73 \pm 1,72) \%$. Menurut Kompiang (2009), waktu pemberian probiotik terbaik yaitu pada saat ternak masih muda, karena lebih efektif dan akan terlihat pengaruhnya dalam hal penyerapan nutrisi, sehingga akan mempengaruhi jumlah ovum yang dihasilkan dan produksi telur yang dihasilkan dapat optimal. Adanya peningkatan rataan produksi telur dari perlakuan $\mathrm{P} 0$ sebesar $(73,70 \pm 1,90) \%$ menjadi $(74,73 \pm 1,72)$ $\%$ pada perlakuan P3, menunjukkan adanya pengaruh kerja dari imbuhan pakan. Seperti halnya asam organik yang ikut berperan dalam peningkatan produksi telur, melalui asam sitrat yang terkandung didalam belimbing wuluh yang kemudian asam tersebut akan membantu dalam proses enzimatik, yang membuat keadaan $\mathrm{pH}$ saluran pencernaan menjadi asam, sehingga penyerapan nutrien seperti protein, kalsium dan fosfor dapat optimal, kemudian diserap oleh usus halus dan dialirkan keseluruhnya guna mencukupi kebutuhan tubuh termasuk produksi telur (Prahadi, Widodo dan Djunaidi, 2015). Nutrisi yang diserap secara optimal akan membantu dan menunjang kebutuhan harian pada ternak, sehingga meningkatkan produktivitasnya.

\section{Berat Telur}

Rataan berat telur dari hasil penelitian (Tabel 1.) penambahan probiotik tepung dan tepung belimbing wuluh dalam pakan menunjukkan bahwa perlakuan tidak memberikan perbedaan yang nyata $(P>0.05)$. Rataan berat telur tertinggi ada pada perlakuan P3 sebesar $(55,05 \pm 1,50) \mathrm{g} /$ butir. Tiap perlakuan pada P0, P1, P2 dan P3 dapat dilihat (Tabel 1.), terjadi kecenderungan peningkatan berat telur. Sejalan dengan penelitian Tang, Sieo, Ramasamy, Saad, Wong and Ho (2017), penggunaan probiotik dengan level berbeda pada tiap perlakuan dari umur 20-36 minggu tidak memberikan pengaruh terhadap berat telur namun menunjukkan adanya peningkatan berat telur.

Berat telur juga dipengaruhi oleh beberapa faktor, seperti konsumsi pakan dan juga hen day prodduction (HDP). Selain faktor tersebut, terdapat faktor lain yang mempengaruhi berat telur yaitu, zat gizi yang ada dalam suatu pakan meliputi protein serta asam amino juga ikut berperan dalam mempengaruhi berat telur (Nasution dan Adrizal, 2009). Penggunaan probiotik dan asam organik tidak memberikan pengaruh terhadap peningkatan jumlah nutrisi 
yang sudah ada dalam saluran peencernaan, tetapi menjadikan penyerapan terhadap nutrisi untuk lebih efisien, sehingga tidak memberikan pengaruh perbedaan dengan adanya perlakuan yang dujikan terhadap berat telur.

\section{Egg Mass}

Hasil dari penelitian (Tabel 1.) menunjukkan bahwa penggunaan probiotik tepung dan tepung belimbing wuluh dalam pakan tidak memberikan perbedaan yang nyata $(P>0.05)$ terhadap egg mass atau massa telur. Namun, apabila dilihat dari hasil nilai rataan massa telur terdapat kecenderungan adanya peningkatan nilai rataan dari perlakuan $\mathrm{PO}$ sebesar $(40,10 \pm 1,23) \mathrm{g} /$ ekor/hari menjadi sebesar $(41,14 \pm 1,58) \mathrm{g} / \mathrm{ekor} /$ hari pada perlakuan P3, perlakuan tertinggi ada pada perlakuan P3. Sesuai Tang et al (2017), probiotik yang ditambahkan dalam pakan ayam petelur tidak memberikan pengaruh yang nyata terhadap massa telur atau egg mass, namun menunjukkan peningkatan pada tiap perlakuan. Rataan egg mass tertinggi ada pada perlakuan P3 yaitu $(41,14 \pm 1,58)$ g/ekor/hari.

Egg mass merupakan hasil perkalian dari hen day production dan berat telur, sehingga rataan egg mass bergantung pada faktor keduanya. Sehingga, apabila dari kedua faktor tersebut terdapat kenaikan nilai maka nilai dari massa telur atau egg mass juga akan mengalami peningkatan (Cath, Bozkurt, Kucukyilmaz, Cmar, Bintas, Coven and Atik, 2012). Rataan massa dari perlakuan P0 hingga P3 menunjukkan adanya peningkatan sebesar $2,6 \%$, hal tersebut dapat dipastikan tidak lepas dari peranan probiotik dan asam organik yang ditambahkan dalam pakan memiliki mekanisme kerja yang sinergis. Asam organik menciptakan kondisi asam pada saluran cerna yang kemudian memicu bakteri probiotik untuk bekerja optimal, sehingga luas permuakaan dari usus meningkat dan nutrisi yang terserap meliputi asam amino dan kalsium mampu dioptimalkan dan berpengaruh pada produktivitas ayam telur harian. Menurut
Novak, Yakout and Scheideler (2006), konsumsi protein selama periode bertelur berlangsung, sangat mempengaruhi periode bertelur, sehingga asupan protein yang cukup sesuai dengan kebutuhan akan menghasilkan massa telur yang sesuai.

\section{Konversi Pakan}

Hasil penelitian penggunaan probiotik tepung dan tepung belimbing wuluh sebagai perlakuan dalam pakan dapat dilihat pada Tabel 1. Hasil tersebut menunjukkan bahwa perlakuan tidak memberikan perbedaan yang nyata $(P>0.05)$ terhadap konversi pakan. Selaras dengan pengukuran parameter-parameter sebelumnya, secara statistik, konversi pakan tidak memberikan pengaruh yang nyata, namun dapat dilihat (Tabel 1.) bahwa rataan nilai konversi pakan cendurung menurun dengan semakin tinggi level pemberian imbuhan pakan. Perlakuan P3 menunjukkan rataan nilai konversi pakan terbaik yaitu $(2,63 \pm 0,09)$ dan perlakuan P0 sebagai kontrol memiliki nilai konversi pakan yang cukup tinggi, sebesar $(2,73 \pm 0,10)$. Tidak adanya pengaruh nyata pada nilai konversi pakan, dikarenakan memang pemberian probiotik tepung dan asam organik (dalam bentuk tepung belimbing wuluh) tidak memberikan pengaruh secara langsung terhadap konversi pakan, melainkan perlakuan dengan probiotik dan asam organik ini hanya berfungsi untuk menciptakan keasaman pada beberapa bagian di saluran pencernaan agar dapat mengoptimalkan pencernaan dan penyerapan nutrien pakan, yang mana konsumsi pakan dan nutrien dalam pakan ini yang mempengaruhi konversi pakan (Nugroho, Wahyuni dan Suthama, 2016).

Rataan konversi pakan pada penelitian berkisar di angka 2,63-2,73, nilai konversi ini dapat dikatakan tidak begitu baik apabila dibandingkan dengan standar konversi pakan yang sesuai dengan umur ayam petelur umumnya. Hal ini dimungkinkan karena terdapat beberapa faktor penyebab dari umur ternak, kualitas pakan, serta berat telur yang tergantung pada pengaruh genetik, umur dan 
juga kedewasaan pada sistem reproduksi ternak. Menurut Setawati, Afnan dan Ulupi (2016), nilai untuk konversi pakan dikatakan bila sesuai standar yaitu dikisaran 2,1-2,3. Tetapi, dari hasi penelitian tersebut bisa dikatakan bahwa penambahan probiotik dan asam organik memberikan pengaruh yang positif, namun masih belum optimal sebab belum mampu menghasilkan efek secara instant (cepat) pada saluran pencernaan.

\section{SIMPULAN}

Penggunaan probiotik tepung dan tepung belimbing wuluh dalam pakan ayam petelur mampu menurunkan konsumsi pakan dan konversi pakan, serta mampu meningkatkan berat telur, hen day production dan egg mass. Penggunaan imbuhan pakan pada level pemberian $0,8 \%$ probiotik tepung dan $0,75 \%$ tepung belimbing wuluh menghasilkan efek yang cenderung paling baik terhadap produksi ayam petelur.

\section{DAFTAR PUSTAKA}

Astuti, F. K., W. Busono dan O. Sjofjan. 2015. Pengaruh Penambahan Probiotik Cair dalam Pakan terhadap Penampilan Produksi pada Ayam Pedaging. J-PAL. 6(2): 99-104.

Cath, A. U., M. Bozkurt, K. Kucukyilmaz, M. Cmar, E. Bintas, F. Coven and $\mathrm{H}$. Atik. 2012. Performance and Egg Quality of Aged Laying Hens Fed Diets Supplemented with Meat and Bone Meal or Oyster Shell Meal. South African Journal of Animal Science. 42(1): 74-82.

Haryanto, B. 2000. Penggunaan Probiotik dalam Pakan untuk Meningkatkan Kualitas Karkas dan Daging Domba. JITV. 5(4): 1-5.

Hendalia, E., F. Manin, Yusrizal dan G. M. Nasution. 2012. Aplikasi Probiotik untuk Meningkatkan Efisiensi Penggunaan Protein dan Menurunkan Emisi Amonia Ayam Broiler. Agrinak. 2(1): 29-35.
Hutajulu, T. F., E. Azizah dan A. Suherman. 2009. Pemanfaatan Alfa Hidroksi Karboksilat (AHA) dari Ekstrak Belimbing Wuluh (Averrhoa bilimbi L) untuk Skin Care. Jurnal Riset Industri. 3(1): 64-74.

Jannah, S. N., A. Dinoto, K. G. Wiryawan and Rusmana. 2014. Characteristics of Lactic Acid Bacteria Isolated from Gastrointestinal Tract of Cemani Chicken and Their Potential Use as Probiotics. Media Peternakan. 37(3): 182-189.

Kompiang, I. P. 2000. Pengaruh Suplementasi Kultur Bacillus spp Melalui Pakan atau Air Minum terhadap Kinerja Ayam Petelur. JITV. 5(4): 2015-219.

Kompiang, I. P. 2009. Pemanfaatan Mikroorganisme Sebagai Probiotik untuk Meningkatkan Produksi Ternak Unggas di Indonesia. Pusat Penelitian dan Pengembangan Peternakan Bogor. 2(3): 177-191.

Manin F., E. Hendalia, Yusrizal dan Nurhayati. 2005. Efektivitas Probiotik (Bacillus circulans dan bacillus $\mathrm{sp}$ ) Asal Saluran Pencernaan Itik Lokal Kerinci sebagai Pengganti Antibiotik Terhadap Performan Ternak Unggas. Laporan Hibah Bersaing $X$ Tahun Ke-2. Fakultas Peternakan. Universitas Jambi.

Nasution, S dan Adrizal. 2009. Pengaruh Pemberian Level Protein-Energi Ransum yang Berbeda Terhadap Kualitas Telur Ayam Buras. Seminar Nasional Teknologi Peternakan dan Veteriner. pp: 105-116.

Novak, C., H. M. Yakout and S. E. Scheideler. 2006. The Effect of Dietary Protein Level and Total Sulfur Amino Acid: Lysine Ratio on Egg Production Parameters and Egg Yield in HyLine W-98 Hens. Poultry Science Journal. 85: 2195-2206.

Nugroho, T. S., H. I. Wahyuni, N. Suthama. 2016. Pengaruh Penambahan Asam Sitrat dalam Ransum sebagai 
Wijayanti \& Nugroho. 2020

Acidifier terhadap Kecernaan Protein dan Bobot Badan Akhir pada Itik Jantan Lokal. Agromedia. 34(2): 49-53.

Prahadi, J. A., E. Widodo dan I. H. Djunaidi. 2015. Pengaruh Penambahan Sari Belimbing Wuluh (Averrhoa bilimbi) sebagai Acidfier dalam Pakan Terhadap Penampilan Produksi Ayam Petelur. Jurnal Nutrisi Ternak. 1(1): 10-18.

Reid, G. 2016. Probotics: Definition, Scope and Mechanism of Action. Best Practice and Research Clinical Gastroenterology. 30: 17-25.

Setiawati, T., R. Afnan dan N. Ulupi. 2016. Performa Produksi dan Kualitas Telur Ayam Petelur pada Sistem Litter dan Cage dengan Suhu Kandang Berbeda. Jurnal IImu Produksi dan Teknologi Hasil Peternakan. 4(1): 197-203.

Sharma, K. G., V. K. Vidyarthi, K. Archana and Zuyie. $2016 . \quad$ Probiotic Supplementation in the Diet of Rabbits. Livestock Research International Journal. 4(1): 1-10.

Tang, S. G. H., C. C. Sieo, K. Ramasamy, W. Z. Saad, H. K. Wong and Y. W. Ho. 2017. Performance, Biochemical and Haematological Response, and Relative Organ Weights of Laying Hens Fed Diets Supplemented with Prebiotic, Probiotic and Synbiotic. Veterinary Research. 13: 248.

Yuliansyah, M. F., E. Widodo dan I. H. Djunaidi. 2014. Pengaruh Penambahan Sari Buah Belimbing Wuluh (Averrhoa bilimbi L) sebagai Acidifier dalam Pakan terhadap Kualitas Internal Telur Ayam Petelur. Jurnal Nutrisi Ternak. 1(1):19-26. 